International Journal of Clinical Chemistry and Laboratory Medicine (IJCCLM)

Volume 6, Issue 2, 2020, PP 12-18

ISSN No. (Online) 2455-7153

DOI: http://dx.doi.org/10.20431/2455-7153.0602002

www.arcjournals.org

\title{
A Narrative Review of ATM Diagnosis Methods: Comparative Analyzing
}

\author{
Lisiane Cervieri Mezzomo*, Silvia Maria Spalding, Luciane Noal Calil, Renata Pereira \\ Limberger, Adelina Mezzari
}

Analysis Departament, Faculty of Pharmacy, Federal University of Rio Grande do Sul, Brazil.

*Corresponding Author: Lisiane Cervieri Mezzomo, Analysis Departament, Faculty of Pharmacy, Federal University of Rio Grande do Sul, Brazil

\begin{abstract}
Germline mutations are the underlying cause of AT syndrome which predisposes to a wide spectrum of early-onset cancers, particularly of lymphoid origin. Besides that, some studies have been pointed out that AT mutation carriers, generally healthy, can have a reduced lifespan due to cancer, specially breast and gastrointestinal tract and also ischemic heart disease. Because AT syndrome is so rare, the symptoms or criteria for making a diagnosis are not familiar in the medical field. A diagnosis of AT can usually be made by the combination of clinical features and specific laboratory abnormalities, mesasured by a wide range of methods.
\end{abstract}

Here, we summarize the current knowledge on ATM variations detection methods, as flow cytometry, immunohistochemistry (IHC), whestern blotting and real-time polymerase chain reaction (RT-PCR). Also, we delineate the recent literature about ATM as a cancer biomarker and a potential target for anti-cancer therapies.

Keywords: Ataxia-Telangiectasia Mutated; Heterozygozys, Laboratory Measurement, Detection Methods, Protein Activity.

\section{INTRODUCTION}

The ataxia-telangiectasia mutated (ATM) gene was first reported in 1995 as the causative gene responsible for Ataxia Telangiectasia Syndrome (AT) (1) ATM gene is located on chromosome 11q2223(2) which encodes a protein of the same name (3) which is a phosphoinositidyl 3-kinase (PI3K)family kinase (4). Is a mediator of DNA damage response which induce cell cycle arrest and DNA repair via their downstream targets. ATM has also an essential role in the DNA double-strand break (DSB), wich is formed when DNA is damaged. For this reason, AT is often referred to as a genome instability syndrome, DNA damage response syndrome or a cromossomal instability syndrome (3).

Most AT patients do not have functional ATM protein due to missense or non-sense mutations in the ATM gene, which result in truncated or unstable ATM variants (5). For this reason, AT is a complex disease, and not every people have the same clinical presentation, symptom constellations and/or laboratory findings. So far, different forms or presentations of AT have been described in the literature, with those more severe variably categorized as "classic", "typical", "early onset" or "childhood onset" AT, while milder forms have been referred to as "variant", "atypical", "late onset" or "adult onset" AT (2).

The diagnosis of AT is usually suspected due to the combination of neurologic clinical characteristics (ataxia, abnormal eye movement control, and postural instability) with one or more of the features which may vary in appearance: telangiectasia, frequent sinopulmonary infections and specific laboratory abnormalities (e.g. IgA deficiency, lymphopenia especially affecting T lymphocytes and increased levels of alpha-fetoprotein). As certain neurological features can arise later, a diagnosis of AT should be carefully considered for any ataxic child with an otherwise elusive diagnosis. A diagnosis of AT can be confirmed by the finding of an absence or deficiency of the ATM protein or its kinase activity in cultured cell lines, and/or identification of the pathological mutations in the ATM gene (2).

Not only AT patients, but also certain ATM heterozygous mutation carriers have a reduced life expectancy and cancer specific types susceptibility, thus, certain ATM heterozygous mutation carriers should be made aware of lifestyle factors that contribute to the development of such diseases (6). 
Considering that downregulation of ATM has been described at mRNA and protein levels, this narrative review aims to outline the ATM gene and investigated techniques to quantify ATMs as part of laboratory protocol methods.

\section{ANALYZING ATM DNA DAMAGE RESPONSE BY FLOW CYTOMETRY}

Flow-and image-assisted cytometric approaches is used to assess the mechanisms and measure the extent of DNA damage response in individual cells, as cell cycle phase position, levels of reactive oxygen species (ROS) and induction of apoptosis. This method requires a few tissue and can count thousands of cells in a few minutes, and multiple antibodies can be used simultaneously on a single tissue sample (7).

Under non-stress conditions ATM forms dimers or oligomers. DNA damage induces intermolecular autophosphorylation of serine 1981 that causes dimer dissociation to monomeric units that initiates intracellular ATM kinase activity (8). So, activation of ATM occurs through its autophosphorylation on Ser1981. Besides that, other autophosphorylation sites as Ser367, Ser1893, and Ser2996 are physiologically important parts of the DNA damage response (9). Also, ATM phosphorylates many proteins involved in control of cell cycle checkpoint, apoptosis, and DNA repair, including p53, Chk2, BRCA1, RPAp34, H2AX, SMC1, FANCD2, Rad17, Artemis, and Nbs1(10).

Examples of cytometric detection of activation of ATM protein kinase using phospho-specific Abs targeting Ser1981 of this protein, are already described. Activation of ATM protein kinase by its phosphorylation on Ser1981 and phosphorylation of histone H2AX on serine $139(\gamma \mathrm{H} 2 \mathrm{AX})$ are the key events reporting DNA damage, primarily formation of DNA DSBs (11).

DSBs are formed when DNA is damaged, whether it is endogenous or exogenous, it is always followed by the phosphorylation of the histone, $\mathrm{H} 2 \mathrm{AX}$, the first step in recruiting and localizing DNA repair proteins. Is phosphorylated by ATM and ATM-Rad3-related (ATR) in the PI3K pathway. All these events are detected immunocytochemically in individual cells using phospho-specific Abs. Flow-and imaging-cytometry, the latter exemplified as laser scanning cytometry, is used to quantify intensity of cellular fluorescence reporting activation of ATM and induction of $\gamma \mathrm{H} 2 \mathrm{AX}$ with respect to cellular DNA content, which in turn reports the cell cycle phase (12)

In one study published by $\mathrm{Li}$ and cols, flow cytometry was used to examine the percentage of cell apoptosis and G2 phase arrest in glioma stem cells. The authors hypothesized that both high expression of ATM and glioma stem cells are responsible for radioresistance in glioma and concluded that silencing of ATM via the siRNA technique improved radiosensitivity of glioma stem cells both in vitro and in vivo (13).

Besides that, the cytometric assay of DNA damage has been used to test the role of ROS as the agents mediating DNA damage. This is seen in one study those suggests that aside from increased tumorigenesis, ATM-deficiency results in altered metabolism, aberrant immune and inflammatory responses and increased levels of ROS. In addition, ATM can be directly activated by ROS, independently from DSB signaling, and has been implicated in mitochondrial quality control, potentially through an ability to localize to mitochondria (14) In this study, data was analyzed using flow citometry and mean fluorescence intensity was used as a measure of ROS (15).

Cytometric assessment of ATM activation provides a very sensitive and convenient tool to estimate DNA damage. Some authors may expect, therefore, that multiparameter cytometry will be the methodology of choice in analysis of reporters of DNA damage such as ATM activation (11).

\section{ATM AS A CANCER BIOMARKER}

$\mathrm{CpG}$ islands hipermetilation studies: epigenetic changes in ATM

Epigenetic characteristics in white blood cells (WBC) are promising risk markers candidates for solid tumors (16). DNA methylation, an epigenetic change, can be a biologic indicator of lifetime accumulation of environmental exposures including ageing, hormones, ionizing radiation, alcohol, smoking, and traffic particles. Dysregulation of epigenetic modification in tumor DNA such as hypermethylation of $\mathrm{CpG}$ islands at the promoters are focused on the most studies on DNA methylation. However, more recently regions around $\mathrm{CpG}$ islands or "shores" and intragenic sequences also appears to be important in tissue-specific expression and may be an important contributor to interindividual variation in gene expression (17). 
The presence of methylated $\mathrm{CpG}$ islands in the promoter region of genes including ATM can suppress their expression. Some studyes suggest that hypermethylation of ATM gene was associated with increased breast cancer risk (16-18). Flanagan and colleagues performed methylation microarray analysis of peripheral blood DNA from 14 women with bilateral breast cancer and demonstrated that was an increased methylation associated with lower ATM mRNA level (16).

The study recently published by Brennan and cols evaluated leukocytes DNA methylation levels at ATM and suggested that it could be a marker of breast cancer risk (18). The evaluation DNA methylation in leukocytes as a biomarker of cancer risk is of particular importance once peripheral blood is often available in prospective cohorts and easier to obtain than tumor or normal tissues samples. It is possible extracted DNA samples from whole blood in the usually $\mathrm{CpG}$ sites and used as the measure of methylation (16).

More recently, Cao and colleagues(19) also studied ATM promoter methylation in pheripheral blood in breast cancer patients and healthy controls. This study, on the other hand, found no significant differences presented in DNA methylation levels of $A T M$ between the sporadic breast cancer cases and the healthy controls. So far, the evidence for powerful blood-based methylation markers is still limited and the identified markers need to be further validated.

Methylation of the ATM promoter is a common event in many types of cancer including breast and colorectal, and may correlate with superior radiosensitivity (20).

These data demonstrates the potential for gene-body epigenetic misregulation of ATM and other cancerrelated genes in peripheral blood DNA that may be useful as a novel marker to estimate cancer risk, breast and others.

In the area of molecular epidemiology, where large numbers, control groups, and robust statistics are mandatory, such studies are facilitated by technical advances allowing the identification of DNA mutations extracted from many biological samples such as plasma, urine, sputum, or exfoliated cells from bronchus, bladder, oral cavity, and esophagus. Besides of that, recent study suggests that High Performance Liquid Chromatography (HPLC) method could be a powerful tool for DNA methylation diagnostics, including prognostication of patients with cancers (21). These data shows us the variability of techniques and samples that can be evaluated, whose applicability depends on the objectives to be pursued.

\section{ATM GENETIC MEASUREMENT}

Mutations and deletions may also serve as biomarkers for diagnosys and targeted therapy

Historically, testing for pathogenic ATM variants/mutations has been limited. However, with the current popularization of gene panel assays, more data about the prevalence of those variants among women with a suspected hereditary predisposition for breast cancer have become available. More than 300 different $A T M$ variants have been identified thus far, and hence, the clinical significance of any individual variant can be challenging to assess (22). Next-generation sequencing of patient tumors was used to identify the variants in the $A T M$ and has revealed that this gene is altered in many human cancers including colorectal, lung, prostate, and breast. Accumulating evidence suggest that at least some ATM variants are associated with an increased risk of breast cancer (23).

The use of multigene panels for the assessment of cancer susceptibility is expanding rapidly in clinical practice, besides this use for stratification of cancer risk be a topic of great controversy in the fields of genetics and medical oncology. Commercially available gene panels for breast cancer risk, as an example, are increasingly used to test for ATM and others, as CHEK2, TP53, PALB2, and several other pathogenic gene variants in women in whom a hereditary predisposition to breast cancer is suspected; however, the clinical implications of some of those variants are unknown $(24,25)$. Testing for moderatepenetrance mutations began in earnest, however, once 'next generation' sequencing technologies made it feasible to screen for mutations in many genes simultaneously using multigene panels (25).

Germline variants in ATM are frequent events in Chronic Lynphocytic Leukemia (CLL), a highly heritable cancer, with a 7.5-fold increased risk in first-degree relatives. In this case, ATM behaving as a classic tumor suppressor gene, showing preferential somatic loss of the wild-type allele $(26,27)$. Aproximatelly $70-80 \%$ of cases exhibit recurrent chromosomal abnormalities that can be identified by fluorescence in situ hybridization (FISH). The most common genomic aberration, include deletion in 
the $\mathrm{q}$ arm of chromosome 11, the site of the ATM gene at (11q22.3). Regarding that, aproximately 30$40 \%$ of such cases have been reported to have a mutation in the remaining ATM allele, currently determined by next-generation sequencing.

After ATM gene mutate, DNA damaged could not be accurately repaired and finally accelerates cancer transformation and proliferation. So, mutations in ATM are linked to poor prognosis and are commonly, but not exclusively, associated with a chromosome 11q23 deletion. Assays of ATM function are currently done by deletion analysis by FISH and ATM mutation analysis (28).

Having this in mind, one study evaluated mutations in the ATM gene determined by next-generation sequencing and revealed 12 somatic mutations and 15 germline mutations in peripheral blood samples from patients with CLL. But, no strong correlation was observed between ATM mutation and function. The authors suggest that a direct assay of the kinase activity should be used an indicator of ATM function in the development of therapies, not the mutation status (28).

Germline ATM sequence variants have been reported in breast cancer cases, however, it is difficult to fully evaluate the increased risk associated with their presence (29).

RNA expression profiles are increasingly used to diagnose and classify disease, based on expression patterns of as many as several thousand RNAs. Is a method for rapid quantitative assessment of hundreds of transcripts is being implemented in hospital laboratories for diagnosis, prognosis, monitoring, and predicting efficacy of therapy ATM-related downstream gene expression profiling may be an useful biomarker for AT carrier detection. Real Time Quantitative RT-PCR and Microarrays are examples of the techniques that measured RNAs. The last, permit measurement of hundreds or even tens of thousands of RNAs simultaneously, including coding and noncoding RNAs (30).

One good example is the measurement of RNA expression in AT carriers. In those patients, one mutant $A T M$ allele are usually not severely affected although they carry an increased risk of developing cancer (31).

RT-PCR assays were used to evaluated ATM gene expression levels in tumor and adjacent normal tissue from patients diagnosed with primary breast cancer. In this study, ATM gene expression was downregulated in those samples and a high $A T M$ gene expression level was associated with a favorable prognosis (32).

A sistematic review published by van Os NJ (33) described that ATM mutation carriers have a reduced life expectancy because of mortality from cancer and ischemic heart diseases and an increased risk of developing cancer in particular breast and cancers of the digestive tract. Because of this, the authors propose that all female carriers of 40-50 years of age and female ATM c.7271T $>$ G mutation carriers from 25 years of age onwards be offered intensified surveillance programs for breast cancer. Furthermore, all carriers should be made aware of lifestyle factors that contribute to the development of cardiovascular diseases and diabetes.

\section{STRUCTURAL AND FUNCTIONAL IMPACT OF ATM MUTATIONS}

Protein expression analysis methods: Imunohistochemistry and Western blotting

Immunohistochemistry (IHC) is a method to identify specific antigens within tissue sections utilizing an antigen-specific antibody and also allows morphologic evaluation by light microscope. Detection at the light microscopic level of antigen-antibody interactions can be achieved by labeling the antibody with a substance that can be visualized, either by conjugation to a fluorescent marker or enzyme followed by colorimetric detection. The advantages of IHC include the preservation of all cells in the tissue and the ability to store the paraffin-embedded tissue for long periods, allowing for reuse with additional antibodies (7).

ATM protein underexpression has been described as an independent prognostic factor to breast cancer (34). In this sense, Feng and cols (35) used immunohistochemistry and automated semi-quantitative digital analysis to detect and quantify ATM and Ki67 in resected primary tumors from patients with early stage hormone receptor-positive breast cancer. The authors indicated that the combination of high ATM and low Ki67 is prognostic of improved survival, independent of tumor size, grade, and lymph node status, and suggest that the prognostic value of Ki67 can be improved by analyzing ATM expression in this type of tumor. 
One study recentlly published analyzed ovarian cancer tissues and ajacent normal tissues by imunohistochemistry and found that ATM expression was increased in tumor tissues compared to adjacent normal tissues. In this study western blotting was also performed which found the same result for ATM protein expression as detected by immunohistochemistry (36). Besides that, recently Jha and cols (37) investigated the expression of nuclear ATM on 69 formalin fixed paraffin embedded choroidal melanoma samples by immunohistochemistry and validated the results by western blotting method. Loss of ATM was observed in $65 \%$ of cases, suggesting this result as a poor prognostic marker in the pathogenesis of uveal melanoma which may lead to increased risk of metastasis.

Using western blotting, it was demonstrated that radiation induced the expression of ATM and p53 protein,

Immunocytochemistry (ICC) is almost the same procedure as IHC, as the steps are the same after fixation of the samples. The difference between two techniques is that ICC examines cell preparations (exfoliated cells, cultured cells and others) while IHC examines tissue sections.

\section{CONCLUDING REMARKS}

ATM deficiency, either in the germ-line or due to epigenetic mechanisms is well known to increase cancer risk and promote breast cancers. Studies on ATM mutations/deletions, ATM variants and kinase activity will further contribute to the understanding of gene-environment interactions in cancer, in particular when comparing variations in ATM mutation patterns in relation to different cohorts of patients. In summary, this review provided an overview of the methods for measuring the ATM gene and activity, described in the literature so far.

\section{REFERENCES}

[1] Savitsky K, Bar-Shira A, Gilad S, Rotman G, Ziv Y, Vanagaite L, Tagle DA, Smith S, Uziel T, Sfez S, Ashkenazi M, Pecker I, Frydman M, Harnik R, Patanjali SR, Simmons A, Clines GA, Sartiel A, Gatti RA, Chessa L, Sanal O, Lavin MF, Jaspers NG, Taylor AM, Arlett CF, Miki T, Weissman SM, Lovett M, Collins FS, Shiloh Y. A single ataxia telangiectasia gene with a product similar to PI-3 kinase. Science 1995; 268, 1749-1753.

[2] Rothblum-Oviatt C, Wright J, Lefton-Greif MA, McGrath-Morrow SA, Crawford TO, Lederman HM. Ataxia telangiectasia: a review. Orphanet journal of rare diseases 2016; 11, 159.

[3] Shiloh Y, Ziv Y. The ATM protein kinase: regulating the cellular response to genotoxic stress, and more. Nature reviews Molecular cell biology 2013; 14, 197-210.

[4] Ambrose M, Gatti RA. Pathogenesis of ataxia-telangiectasia: the next generation of ATM functions. Blood $2013 ; 121,4036-4045$.

[5] Zhang N, Chen P, Khanna KK, Scott S, Gatei M, Kozlov S, Watters D, Spring K, Yen T, Lavin MF. Isolation of full-length ATM cDNA and correction of the ataxia-telangiectasia cellular phenotype. Proceedings of the National Academy of Sciences of the United States of America 1997; 94, 8021-8026.

[6] Fukunaga H, Taki Y, Prise KM. Diversity of ATM gene variants: a population-based genome data analysis for precision medicine. Human genomics 2019; 13, 38.

[7] Morgan-Bathke M, Harteneck D, Jaeger P, Sondergaard E, Karwoski R, Espinosa De Ycaza A, CarranzaLeon BG, Faubion WA, Jr., Oliveira AM, Jensen MD. Comparison of Methods for Analyzing Human Adipose Tissue Macrophage Content. Obesity 2017; 25, 2100-2107.

[8] Bakkenist CJ, Kastan MB. DNA damage activates ATM through intermolecular autophosphorylation and dimer dissociation. Nature 2003; 421, 499-506.

[9] Kozlov S, Gueven N, Keating K, Ramsay J, Lavin MF. ATP activates ataxia-telangiectasia mutated (ATM) in vitro. Importance of autophosphorylation. The Journal of biological chemistry 2003; 278, 9309-9317.

[10] Lee JH, Paull TT. Activation and regulation of ATM kinase activity in response to DNA double-strand breaks. Oncogene 2007; 26, 7741-7748.

[11] Tanaka T, Huang X, Halicka HD, Zhao H, Traganos F, Albino AP, Dai W, Darzynkiewicz Z. Cytometry of ATM activation and histone H2AX phosphorylation to estimate extent of DNA damage induced by exogenous agents. Cytometry Part A: the journal of the International Society for Analytical Cytology 2007; 71, 648-661.

[12]Zhao H, Halicka HD, Garcia J, Li J, Darzynkiewicz Z. ATM Activation and H2AX Phosphorylation Induced by Genotoxic Agents Assessed by Flow- and Laser Scanning Cytometry. Methods in molecular biology 2017; 1599, 183-196.

[13] Li Y, Li L, Wu Z, Wang L, Wu Y, Li D, Ma U, Shao J, Yu H, Wang D. Silencing of ATM expression by siRNA technique contributes to glioma stem cell radiosensitivity in vitro and in vivo. Oncology reports 2017; $38,325-335$. 
[14] Guo Z, Kozlov S, Lavin MF, Person MD, Paull TT. ATM activation by oxidative stress. Science 2010; 330 , 517-521.

[15] Chen WT, Ebelt ND, Stracker TH, Xhemalce B, Van Den Berg CL, Miller KM. ATM regulation of IL-8 links oxidative stress to cancer cell migration and invasion. eLife 2015; 4.

[16] Flanagan JM, Munoz-Alegre M, Henderson S, Tang T, Sun P, Johnson N, Fletcher O, Dos Santos Silva I, Peto J, Boshoff C, Narod S, Petronis A. Gene-body hypermethylation of ATM in peripheral blood DNA of bilateral breast cancer patients. Human molecular genetics 2009; 18, 1332-1342.

[17] Tang Q, Cheng J, Cao X, Surowy H, Burwinkel B. Blood-based DNA methylation as biomarker for breast cancer: a systematic review. Clinical epigenetics 2016; 8, 115.

[18] Brennan K, Garcia-Closas M, Orr N, Fletcher O, Jones M, Ashworth A, Swerdlow A, Thorne H, Investigators KC, Riboli E, Vineis P, Dorronsoro M, Clavel-Chapelon F, Panico S, Onland-Moret NC, Trichopoulos D, Kaaks R, Khaw KT, Brown R, Flanagan JM. Intragenic ATM methylation in peripheral blood DNA as a biomarker of breast cancer risk. Cancer research 2012; 72, 2304-2313.

[19] Cao X, Tang Q, Holland-Letz T, Gundert M, Cuk K, Schott S, Heil J, Golatta M, Sohn C, Schneeweiss A, Burwinkel B. Evaluation of Promoter Methylation of RASSF1A and ATM in Peripheral Blood of Breast Cancer Patients and Healthy Control Individuals. International journal of molecular sciences 2018; 19.

[20] Yan X, Wu T, Tang M, Chen D, Huang M, Zhou S, Zhang H, Yang X, Li G. Methylation of the ataxia telangiectasia mutated gene (ATM) promoter as a radiotherapy outcome biomarker in patients with hepatocellular carcinoma. Medicine 2020; 99, e18823.

[21] Yotani T, Yamada Y, Arai E, Tian Y, Gotoh M, Komiyama M, Fujimoto H, Sakamoto M, Kanai Y. Novel method for DNA methylation analysis using high-performance liquid chromatography and its clinical application. Cancer science 2018; 109, 1690-1700.

[22] Ahmed M, Rahman N. ATM and breast cancer susceptibility. Oncogene 2006; 25, 5906-5911.

[23] Southey MC, Goldgar DE, Winqvist R, Pylkas K, Couch F, Tischkowitz M, Foulkes WD, Dennis J, Michailidou K, van Rensburg EJ, Heikkinen T, Nevanlinna H, Hopper JL, Dork T, Claes KB, Reis-Filho J, Teo ZL, Radice P, Catucci I, Peterlongo P, Tsimiklis H, Odefrey FA, Dowty JG, Schmidt MK, Broeks A, Hogervorst FB, Verhoef S, Carpenter J, Clarke C, Scott RJ, Fasching PA, Haeberle L, Ekici AB, Beckmann MW, Peto J, Dos-Santos-Silva I, Fletcher O, Johnson N, Bolla MK, Sawyer EJ, Tomlinson I, Kerin MJ, Miller N, Marme F, Burwinkel B, Yang R, Guenel P, Truong T, Menegaux F, Sanchez M, Bojesen S, Nielsen SF, Flyger H, Benitez J, Zamora MP, Perez JI, Menendez P, Anton-Culver H, Neuhausen S, Ziogas A, Clarke CA, Brenner H, Arndt V, Stegmaier C, Brauch H, Bruning T, Ko YD, Muranen TA, Aittomaki K, Blomqvist C, Bogdanova NV, Antonenkova NN, Lindblom A, Margolin S, Mannermaa A, Kataja V, Kosma VM, Hartikainen JM, Spurdle AB, Investigators K, Australian Ovarian Cancer Study G, Wauters E, Smeets D, Beuselinck B, Floris G, Chang-Claude J, Rudolph A, Seibold P, Flesch-Janys D, Olson JE, Vachon C, Pankratz VS, McLean C, Haiman CA, Henderson BE, Schumacher F, Le Marchand L, Kristensen V, Alnaes GG, Zheng W, Hunter DJ, Lindstrom S, Hankinson SE, Kraft P, Andrulis I, Knight JA, Glendon G, Mulligan AM, Jukkola-Vuorinen A, Grip M, Kauppila S, Devilee P, Tollenaar RA, Seynaeve C, Hollestelle A, GarciaClosas M, Figueroa J, Chanock SJ, Lissowska J, Czene K, Darabi H, Eriksson M, Eccles DM, Rafiq S, Tapper WJ, Gerty SM, Hooning MJ, Martens JW, Collee JM, Tilanus-Linthorst M, Hall P, Li J, Brand JS, Humphreys K, Cox A, Reed MW, Luccarini C, Baynes C, Dunning AM, Hamann U, Torres D, Ulmer HU, Rudiger T, Jakubowska A, Lubinski J, Jaworska K, Durda K, Slager S, Toland AE, Ambrosone CB, Yannoukakos D, Swerdlow A, Ashworth A, Orr N, Jones M, Gonzalez-Neira A, Pita G, Alonso MR, Alvarez N, Herrero D, Tessier DC, Vincent D, Bacot F, Simard J, Dumont M, Soucy P, Eeles R, Muir K, Wiklund F, Gronberg H, Schleutker J, Nordestgaard BG, Weischer M, Travis RC, Neal D, Donovan JL, Hamdy FC, Khaw KT, Stanford JL, Blot WJ, Thibodeau S, Schaid DJ, Kelley JL, Maier C, Kibel AS, Cybulski C, Cannon-Albright L, Butterbach K, Park J, Kaneva R, Batra J, Teixeira MR, Kote-Jarai Z, Olama AA, Benlloch S, Renner SP, Hartmann A, Hein A, Ruebner M, Lambrechts D, Van Nieuwenhuysen E, Vergote I, Lambretchs S, Doherty JA, Rossing MA, Nickels S, Eilber U, Wang-Gohrke S, Odunsi K, Sucheston-Campbell LE, Friel G, Lurie G, Killeen JL, Wilkens LR, Goodman MT, Runnebaum I, Hillemanns PA, Pelttari LM, Butzow R, Modugno F, Edwards RP, Ness RB, Moysich KB, du Bois A, Heitz F, Harter P, Kommoss S, Karlan BY, Walsh C, Lester J, Jensen A, Kjaer SK, Hogdall E, Peissel B, Bonanni B, Bernard L, Goode EL, Fridley BL, Vierkant RA, Cunningham JM, Larson MC, Fogarty ZC, Kalli KR, Liang D, Lu KH, Hildebrandt MA, Wu X, Levine DA, Dao F, Bisogna M, Berchuck A, Iversen ES, Marks JR, Akushevich L, Cramer DW, Schildkraut J, Terry KL, Poole EM, Stampfer M, Tworoger SS, Bandera EV, Orlow I, Olson SH, Bjorge L, Salvesen HB, van Altena AM, Aben KK, Kiemeney LA, Massuger LF, Pejovic T, Bean Y, Brooks-Wilson A, Kelemen LE, Cook LS, Le ND, Gorski B, Gronwald J, Menkiszak J, Hogdall CK, Lundvall L, Nedergaard L, Engelholm SA, Dicks E, Tyrer J, Campbell I, McNeish I, Paul J, Siddiqui N, Glasspool R, Whittemore AS, Rothstein JH, McGuire V, Sieh W, Cai H, Shu XO, Teten RT, Sutphen R, McLaughlin JR, Narod SA, Phelan CM, Monteiro AN, Fenstermacher D, Lin HY, Permuth JB, Sellers TA, Chen YA, Tsai YY, Chen Z, GentryMaharaj A, Gayther SA, Ramus SJ, Menon U, Wu AH, Pearce CL, Van Den Berg D, Pike MC, Dansonka- 
Mieszkowska A, Plisiecka-Halasa J, Moes-Sosnowska J, Kupryjanczyk J, Pharoah PD, Song H, Winship I, Chenevix-Trench G, Giles GG, Tavtigian SV, Easton DF, Milne RL. PALB2, CHEK2 and ATM rare variants and cancer risk: data from COGS. Journal of medical genetics 2016; 53, 800-811.

[24] Robson ME, Bradbury AR, Arun B, Domchek SM, Ford JM, Hampel HL, Lipkin SM, Syngal S, Wollins DS, Lindor NM. American Society of Clinical Oncology Policy Statement Update: Genetic and Genomic Testing for Cancer Susceptibility. Journal of clinical oncology : official journal of the American Society of Clinical Oncology 2015; 33, 3660-3667.

[25] Kurian AW, Hare EE, Mills MA, Kingham KE, McPherson L, Whittemore AS, McGuire V, Ladabaum U, Kobayashi Y, Lincoln SE, Cargill M, Ford JM. Clinical evaluation of a multiple-gene sequencing panel for hereditary cancer risk assessment. Journal of clinical oncology : official journal of the American Society of Clinical Oncology 2014; 32, 2001-2009.

[26] Tiao G, Improgo MR, Kasar S, Poh W, Kamburov A, Landau DA, Tausch E, Taylor-Weiner A, Cibulskis C, Bahl S, Fernandes SM, Hoang K, Rheinbay E, Kim HT, Bahlo J, Robrecht S, Fischer K, Hallek M, Gabriel S, Lander ES, Stilgenbauer S, Wu CJ, Kiezun A, Getz G, Brown JR. Rare germline variants in ATM are associated with chronic lymphocytic leukemia. Leukemia 2017; 31, 2244-2247.

[27] Goldin LR, Pfeiffer RM, Li X, Hemminki K. Familial risk of lymphoproliferative tumors in families of patients with chronic lymphocytic leukemia: results from the Swedish Family-Cancer Database. Blood 2004; 104, 1850-1854.

[28] Jiang Y, Chen HC, Su X, Thompson PA, Liu X, Do KA, Wierda W, Keating MJ, Plunkett W. ATM function and its relationship with ATM gene mutations in chronic lymphocytic leukemia with the recurrent deletion (11q22.3-23.2). Blood cancer journal 2016; 6, e465.

[29] Hall J. The Ataxia-telangiectasia mutated gene and breast cancer: gene expression profiles and sequence variants. Cancer letters 2005; 227, 105-114.

[30] Tang W, Hu Z, Muallem H, Gulley ML. Quality assurance of RNA expression profiling in clinical laboratories. The Journal of molecular diagnostics : JMD 2012; 14, 1-11.

[31]Zhang L, Simpson DA, Innes CL, Chou J, Bushel PR, Paules RS, Kaufmann WK, Zhou T. Gene expression signatures but not cell cycle checkpoint functions distinguish AT carriers from normal individuals. Physiological genomics 2013; 45, 907-916.

[32] Ye C, Cai Q, Dai Q, Shu XO, Shin A, Gao YT, Zheng W. Expression patterns of the ATM gene in mammary tissues and their associations with breast cancer survival. Cancer 2007; 109, 1729-1735.

[33] van Os NJ, Roeleveld N, Weemaes CM, Jongmans MC, Janssens GO, Taylor AM, Hoogerbrugge N, Willemsen MA. Health risks for ataxia-telangiectasia mutated heterozygotes: a systematic review, metaanalysis and evidence-based guideline. Clinical genetics 2016; 90, 105-117.

[34] Bueno RC, Canevari RA, Villacis RA, Domingues MA, Caldeira JR, Rocha RM, Drigo SA, Rogatto SR. ATM down-regulation is associated with poor prognosis in sporadic breast carcinomas. Annals of oncology : official journal of the European Society for Medical Oncology 2014; 25, 69-75.

[35]Feng X, Li H, Kornaga EN, Dean M, Lees-Miller SP, Riabowol K, Magliocco AM, Morris D, Watson PH, Enwere EK, Bebb G, Paterson A. Low Ki67/high ATM protein expression in malignant tumors predicts favorable prognosis in a retrospective study of early stage hormone receptor positive breast cancer. Oncotarget 2016; 7, 85798-85812.

[36]Liu HY, Zhang YY, Zhu BL, Feng FZ, Zhang HT, Yan H, Zhou B. MiR-203a-3p regulates the biological behaviors of ovarian cancer cells through mediating the Akt/GSK-3beta/Snail signaling pathway by targeting ATM. Journal of ovarian research 2019; 12, 60.

[37] Jha J, Singh MK, Singh L, Pushker N, Bajaj MS, Sen S, Kashyap S. Prognostic relevance of ATM protein in uveal melanoma and its association with clinicopathological factors. International journal of clinical oncology 2019; 24, 1526-1535.

Citation: Lisiane Cervieri Mezzomo et.al., (2020). "A Narrative Review of ATM Diagnosis Methods: Comparative Analyzing”, International Journal of Clinical Chemistry and Laboratory Medicine (IJCCLM), 6(2), pp.12-18. DOI: http://dx.doi.org/10.20431/2455-7153.0602002

Copyright: (C) 2020 Authors, This is an open-access article distributed under the terms of the Creative Commons Attribution License, which permits unrestricted use, distribution, and reproduction in any medium, provided the original author and source are credited. 